\title{
SEMIOTIC ANALYSIS OF ADAPTED ADVERTISING COMMUNICATION BETWEEN CHINA AND WESTERN PEPSI “RISING” GLOBAL ADVERTISING
}

\author{
Elizabeth Susanti Gunawan \\ (Email: elizabeth.susanti@yahoo.com) \\ Advertising Department \\ School of Journalism and Communication \\ Xiamen University, China \\ 422 Siming Nan Rd, Siming Qu, Xiamen Shi, Fujian Sheng, China, 361005
}

\begin{abstract}
ABSTRAK
Banyak iklan global dibuat lebih homogen untuk berbagai negara dengan tujuan untuk menekankan brand positioning yang sama. Komunikasi yang konsisten dilakukan dengan membuat pesan iklan yang sama agar konsumen dapat dengan mudah mengenalinya dimanapun. Strategi ini juga menguntungkan dalam mengurangi biaya iklan karena mereka tidak harus mendesain ulang iklan baru untuk setiap negara. Iklan televisi Pepsi "Rising" dibuat oleh Agen CLM BBDO Paris untuk digunakan sebagai iklan global Pepsi untuk Afrika, Laut Karibia, Amerika Tengah, Amerika Selatan, Eropa, Oceania, termasuk Asia (India). Iklan untuk negara lain hanya dipersingkat dan dilakukan dubbing dari bahasa asing agar sesuai dengan bahasa lokal, tapi untuk pasar di China, mereka juga mengubah aktor dan beberapa atribut dengan alur cerita dan gambar dengan tingkat kemiripan yang sangat tinggi. Mereka menggunakan satu iklan global untuk banyak negara, tapi dengan sengaja mengubah iklan untuk pasar China agar sesuai dengan nilai budaya lokal. Penelitian ini menggunakan semiotik Roland Barthes untuk menganalisis perbedaan makna denotasi antara iklan Pepsi global dan iklan Pepsi China yang memiliki gambar visual dan plot yang mirip di level denotasi. Penelitian ini bertujuan untuk mengetahui setiap elemen yang dapat mengubah pesan dan ideologi dalam iklan. Hasil akhir yang diperoleh adalah perbedaan yang signifikan antara iklan yang mewakili perkembangan budaya masing-masing yang unik.
\end{abstract}

Kata kunci: iklan adaptasi, iklan China; periklanan global; individualisme-kolektivisme; analisis semiotik

\begin{abstract}
Many global advertisements are created homogeneously to emphasize the same brand positioning. A consistent communication carried through the same advertising message is expected to help consumers easily recognize the brand anywhere. This strategy is also useful in reducing advertising cost because they don't have to redesign new advertisements for different countries. Pepsi "Rising" TV Commercial was created by CLM BBDO Paris Agency as the Pepsi global advertising for Africa, Caribbean Sea, Central America, South America, Europe, Oceania, and Asia (India). The advertisements for other countries were only shortened and dubbed to make them fit with local languages. However, for the Chinese market, the agency changed the actor and some storyline attributes with those similar to the original ones. They used one global advertisement for many countries, but they deliberately changed it for the Chinese market. This study uses Roland Barthes' semiotic to analyze the connotation level between the Pepsi global advertisement and the Chinese advertisement that have similar visuals and plot lines in the denotation level. This study aims to determine the elements that can change the message and ideology in the advertisement. The final results show significant differences among the advertisements that represent each unique cultural development.
\end{abstract}

Keywords: adapted advertising; Chinese advertising; global advertising; individualism-collectivism; semiotic analysis 
Serat Rupa Journal of Design, May 2017, Vol.1, No.3: 475-495

Elizabeth Susanti Gunawan, Semiotic Analysis of adapted Advertising Communication

Between China and Western Pepsi"Rising" Global Advertising

\section{INTRODUCTION}

Globalization makes equal social and cultural diversity (Robertson, 1992) and also affects advertising displays. In recent years, standardized advertising strategies have become advisable because it can create a uniform brand image and achieve cost savings (Tai, 1997). However, the global advertising strategy's degree and intensity may differ among countries (Samiee et al., 2003). This study examines highly standardized executions of Pepsi advertising notion of "I can" from many elements that appear in similar background pictures. Pepsi is an American product that is sold globally with the position as an innovative, self-expressing, and creative product for young generations. The story is about a young man who determined to make his dream come true. The scene shows the different stages of his life to achieve his dream without worrying about the opinion of others. Pepsi "Rising" global advertising uses the same picture for many countries. They just dubbed the original language into local languages of those countries and shortened the advertising into about 29 seconds. In this research, the author uses the original advertising that has a complete line story to be compared (https://www.youtube.com/watch?v=OCmd5bUu_U0).

Visual advertising can be understood more concisely and efficiently than verbal language. It is important to consider the execution of the ads, how messages are communicated to the audience, especially through visual production techniques (Cho, et al., 1999). For the Chinese market, the Pepsi company have their own important consideration to make the advertisement not only different in some aspects, but also similar in picture and storyline. Pepsi global advertisement was first released in April 2009, and the Chinese advertisement was released in July 2009. The global advertisement plays in 58 seconds while the Chinese advertisement only has about 29 seconds' durations ( https: / /www. youtube.com/ watch? v=_oqn0KH3YJM).

\section{RESEARCH METHOD}

This study examines highly standardized executions of Pepsi advertising for global and Chinese market. The research questions:

- Why is it needed to do the localized advertising specifically for China, whereas Pepsi uses the same advertising for many countries?

- Other than visual translation with highly similar pictures for Chinese advertising, is there any cultural and ideological difference in the visually localized pictures? 
This research uses cinematographic analysis and semiotic analysis to understand the localized discourse in the similar advertisements. The author captured the advertising every 0.5 seconds and compared the overall pictures of these two advertising to each other that presented the same concept. The similar pictures and plot lines were analyzed using Roland Barthes' semiotic to determine any element that can change the message meaning and ideology in advertising. According to Roland Barthes, Semiology involves any system of signs, in the form of images, gestures, sounds, and objects as denotation, connotation meaning, and the relation of all in the ideological system (Barthes, 1967). Denotation level of meaning is the descriptive and literal level of sign; connotation level of meaning is generated by connecting signifiers with cultural concerns, such as beliefs, attitudes, frameworks and ideologies of a social formation (Barker, 2000). The localized advertising conveys different stories, communicating different values, positioning the brand in an entirely different value system and guiding the localized audiences towards different secondary brand associations (Gunawan \& van den Hoven, 2017). The Semiotic model helps to explain anthropological dynamics in locally differentiated advertisement and the dynamic development of global advertisement.

\section{DISCUSSION}

By cutting the pictures every 0.5 seconds, a total of 116 photographs were obtained from the global advertisement and 58 images from the Chinese advertisement.

Table 1. Main cinematographic structures by time

\begin{tabular}{|l|l|l|}
\hline \multicolumn{1}{|c|}{ Scenes } & \multicolumn{1}{|c|}{$\begin{array}{l}\text { global ad } \\
\text { (seconds) }\end{array}$} & \multicolumn{1}{|c|}{$\begin{array}{c}\text { Chinese ad } \\
\text { (seconds) }\end{array}$} \\
\hline The context & 2 & - \\
\hline $\begin{array}{l}\text { Huge mound of } \\
\text { objects }\end{array}$ & 1.5 & 3 \\
\hline $\begin{array}{l}\text { Start the activity with } \\
\text { drink Pepsi }\end{array}$ & 2.5 & 2 \\
\hline Start climbing & 8.5 & 1.5 \\
\hline $\begin{array}{l}\text { Through school (global } \\
\text { ad), family (Chinese ad) }\end{array}$ & 5 & 3.5 \\
\hline Climbing & 7.5 & 2 \\
\hline $\begin{array}{l}\text { Peers (global ad), } \\
\text { Office (Chinese ad) }\end{array}$ & 4.5 & 4 \\
\hline Climbing & 4.5 & 2 \\
\hline Family (global ad) & 4.5 & - \\
\hline Office (global ad) & 6.5 & - \\
\hline Climbing to top of & 3.5 & 4.5 \\
\hline
\end{tabular}




\begin{tabular}{|l|l|l|}
\hline mound & & \\
\hline Shouting on stage & 7.5 & 6.5 \\
\hline Total & $\mathbf{5 8}$ & $\mathbf{2 9}$ \\
\hline
\end{tabular}

\section{Denotation and Connotation Meaning \\ The Context: Huge Mound of Object}

In global advertising, the first scene shows a medium shot of a young man looking up and then a long shot of the young man standing in front of a mound. The medium shot is a signifier to show most of the person's body; and it signifies a personal relationship (Berger, 1991: 26). A long shot is a signifier to show the setting and characters; and it signifies the context, scope, and public distance (Berger, 1991:26). These scenes show the denotation level of the personal relationship between the activity of the young man within the context of the story. Global advertising made a shot of a young man in 2 seconds and a shot of the mound in 1.5 seconds to let audiences think about the relation between the young man and the mound (the mound representing the young man's life). Chinese advertising started directly with a long shot of a young man and a mound in 3 seconds, 2 times longer than the global advertising without any medium shot of the young man before it. The advertisement did not give an obvious direction the person would climb up the mound.

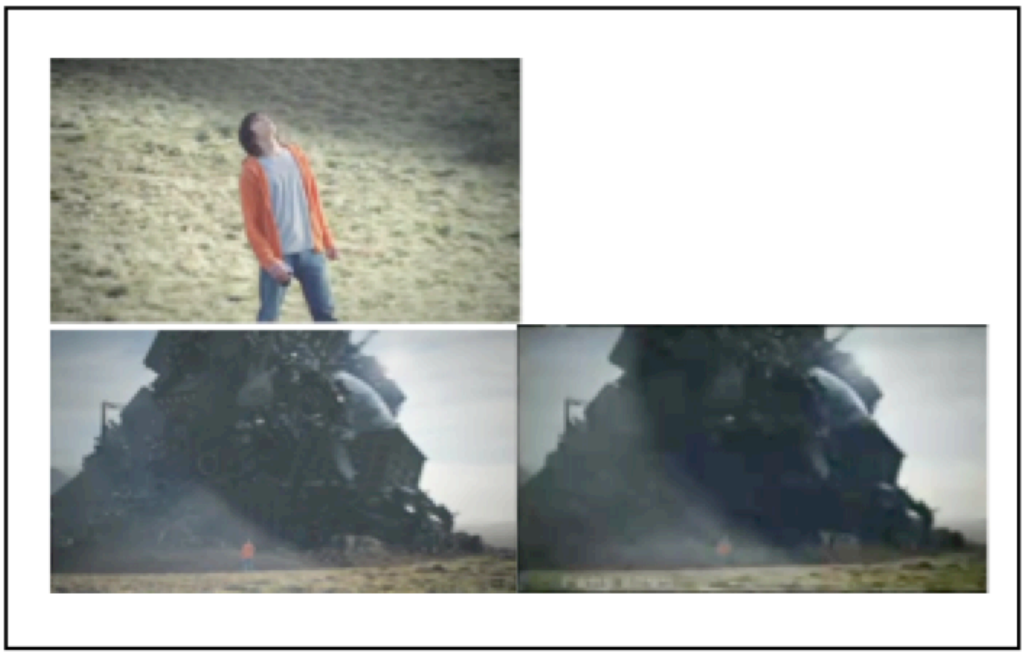

Figure 1. Global advertising: the shot of young man and mound 3.5 seconds, Chinese advertising: the shot of mound 3 seconds (Source: https://www.youtube.com/watch?v=OCmd5bUu_U0; https://www.youtube.com/watch?v=_oqnOKH3YJM)

In the connotation level, the complete and incomplete way of providing information in a story 
shows the different cultural contexts. In low context culture, most of the information is given in the explicit information and direct speech in order to address what is missing in the context. By contrast, Chinese consumer as a high context cultural group, transmitted message with only minimal information, symbolism, nonverbal, and indirect verbal expressions (Hall, 1976: 101). The global advertising that is intended for Western countries with a low context culture is designed with complete information, whereas the Chinese advertising that is intended for a high context cultural group provides the story with less information. The different ways of telling the story implicitly or explicitly represent a different cultural background of audiences.

\section{Start The Activity With Drink Pepsi}

In global advertising, the denotation level shows the young man is drinking Pepsi with his eyes closed and holds the can horizontally, about 100 degrees. The slightly tilted down position of the can will slow down the product inside from flowing too fast and should be drunk slowly in this position. Time seems slower and the young man seems to enjoy his time-consuming Pepsi. In the Chinese advertising, the young man is drinking the Pepsi with his eyes pointing upwards. Based on the previous scene, the young man should stare at the mound of goods. He holds the can pointing upward, more vertical than the global advertisement (about 50 degrees). This upward sloping position makes the Pepsi flow quicker and should be drunk at a faster pace. Time seems to move more rapidly and the young man seems to be thinking something. It seems there should be a relationship between consuming Pepsi and the activity he is doing. 


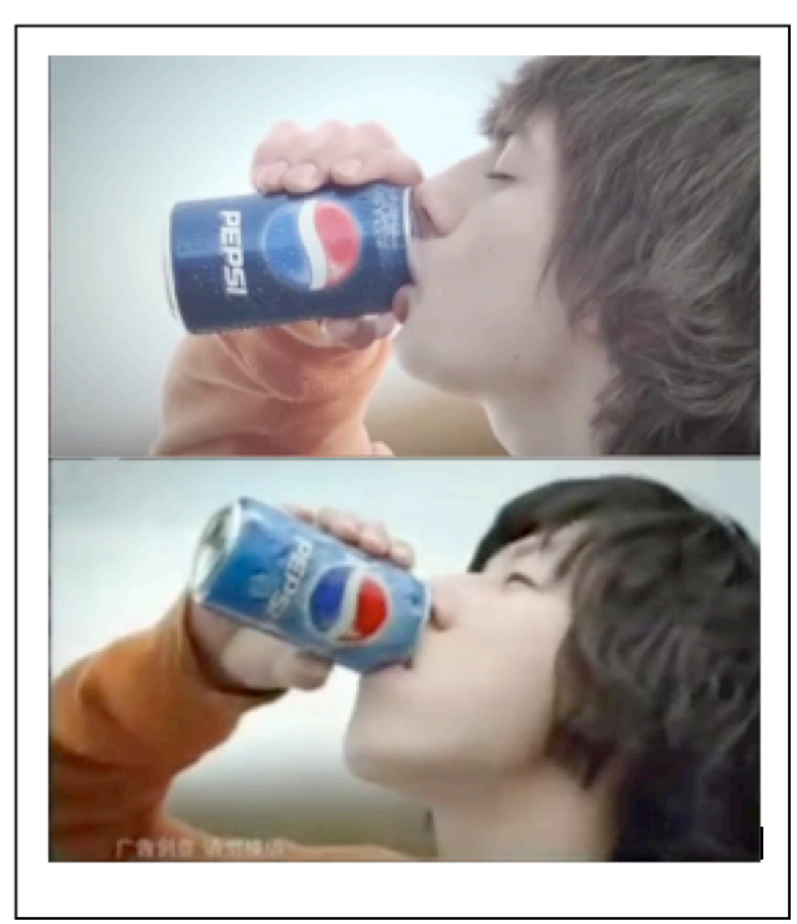

Figure 2. American advertising and Chinese advertising: young man drinking gesture (Source: https://www.youtube.com/watch?v=OCmd5bUu_U0; https://www.youtube.com/watch?v=_oqn0KH3YJM)

In the connotation level, the pictures show the differences of culture in managing time and activity. The concept of time and its usage differs across cultures and are identified as monochronic (M-time) and polychronic (P-time) (Hall, 1976). Monochronic cultures focus on single activity at one particular time and polychronic cultures focus on many activities during the same period. Western countries tend to be more M-time in their culture while South Asian countries, including China, tend to be a more P-time culture (Kaufman, Lane, and Lindquist, 1991). Although India is included in the P-time culture, but there were some other considerations were made by the company to decide if it was really needed to redesign the advertising or not. In Indian version of Pepsi advertising, other than dubbing the language, they considered the global version could still be accepted, while in China, they considered it was needed to be adapted.

\section{Climbing Process}

In the denotation level, the global advertisement shows a shot of the climbing process in a longer period of time than the one in the Chinese advertisement. For example, the first climbing shot before he climbs through the class is 8.5 seconds and after climbing through the class is 7.5 seconds, an overall of 16 seconds. In the Chinese advertisement, the first climbing shot before 
going through the house is 1.5 seconds while after climbing through the house is 2 seconds, an overall of 3.5 seconds. The global advertisement took approximately five times longer to shoot in order to show the process than the Chinese one. The process to climb to the top of the mound seems more important in the global advertisement. In the global one, the young man is also shown climbing on a bicycle wheel and hanging on a car's key. The connotation level could well emphasize that the climbing process is dangerous and hard to get to the summit. Many western countries emphasize on individual performance (Nisbett and Masuda, 2003). The global advertising is concerned with personal uniqueness, personal abilities, and individual skills; it is emphasized that a person can do a good job. The process of doing the activities seems to be more important.

The young man is shown climbing through a mound of symbolic collections. In the global commercial, the mound shows some items like a remote game, a dartboard, glasses, an electric piano, a bicycle wheel, a music player, a guitar, a dice, car keys, a radio, drums, and a cassette. The Chinese one shows some items like a dartboard, a guitar, a music player, a Rubik's cube, a radio, drums, a cassette, and a speaker. The goods used by that particular country influence these differences. The denotations of all these goods are used for playing games, music, and transportation which are symbolic forms/connotations of pleasures, hobbies, and facilities left behind by the young man to move forward towards the summit.

\section{Dice or Rubik's Cube}

The denotation level in the global advertising shows a dice is falling down the mound as the young man is climbing to the top. The dice is usually used for playing games and especially for gambling. It is a strong symbol/connotation to represent taking a gamble, gaining more fortune, and taking risk in climbing to the top. The young man climbing up conveys the meaning of taking a risk in his life. Many western countries emphasize more on individual variety and pleasure than on a collectivist society. The dice in this advertisement does not only show a tool to play a game, but also conveys an individualistic ideology of the western culture and a symbol of the individualistic nature of the product. In the Chinese advertisement, the dice is replaced with a Rubik's Cube. The Rubik's Cube is a game to advance brain development and sharpen the abilities of one's mind. The Rubik's Cube is famous throughout the world and is an iconic puzzle well known to have a rich underlying mathematical structure (Demaine et al., 
2011). It has a connotative meaning of a seeker of knowledge. As the young man climbs up, the young man becomes a symbol of a seeker of knowledge climbing up to achieve the ultimate wisdom and knowledge. In China, the influence of parents is fundamental in making the content of an advertisement. The company makes advertisements that aim to demonstrate achievement, sharpen the competitive instincts, and make products as a means to gain what is desired (Doctoroff, 2012). Compared to children's commercials in the western countries, Chinese commercials are less likely to portray an individualistic appeal as something fun or adventurous (Barcus, 1977). The deliberate change of the dice to the Rubik's Cube does not only show the denotation of a different game, but also shows that global advertising contains an individual value such as taking pleasure in risks on one's own, while in Chinese advertisement, although someone struggles by himself, it still contains a collectivism value such as seeking knowledge as what the parents wish for their children.

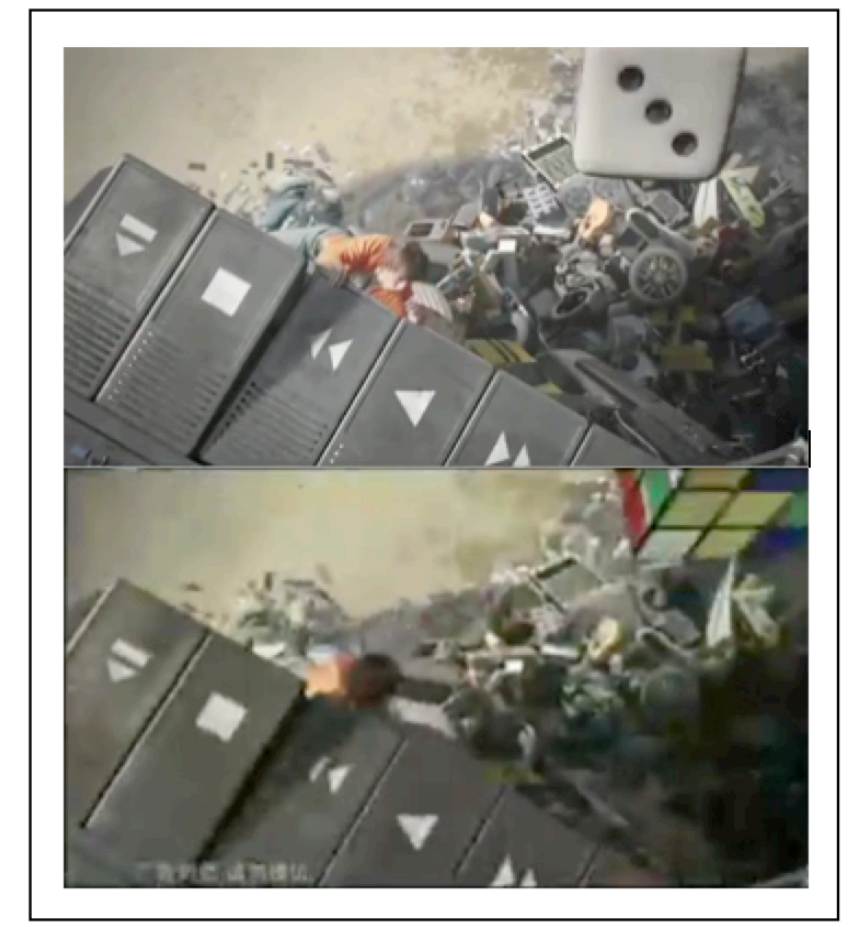

Figure 3. American advertising and Chinese advertising: Dice or Rubik's Cube (Source: https://www.youtube.com/watch?v=OCmd5bUu_U0; https://www.youtube.com/watch?v=_oqnOKH3YJM)

1. THROUGH SOCIAL SOCIETIES (Global ad: school, peers, family, job; Chinese ad: family, job).

In the denotation level, there are different societies in a person's life, such as schools, peers, the family, and jobs. In the global advertisement, the first obstacle the young man passes through is 
his school. A school plays a central role in the life of adolescences. At school, they come not only to study the subjects, but also to serve a latent function in society as socializing children transformed into behaviors like a teamwork (Boundless, 2014). In Western culture, once a child turns 18 , he has the right to control his own life and can choose whether to listen to his parents' guidance or not. It is considered as a preparatory period for the future, a period of individualism, establishing close relationships with peers, starting a job, and gaining increased separation from the parents (Stevenson and Nerison-Low, 2002).

The second challenge the young man passes is his peers. Peers are important to adolescences to develop an identity separated from their parents and exert their independence (Boundless, 2014). In the global advertising, the young man is wearing a working hat and an apron. He is doing a part-time job at a restaurant, then he throws away his hat, which means he quits the job. In some other countries that use this global version advertisement, they cut this part of the advertising. Peers are not considered as an obstacle that they have to run from.

The third social obstacle the young man passed was his family. In the West, many parents put their trust and rely heavily on the federal educational system to enlighten and train their children for the next step of independence, and besides the academic achievement, many parents are more concerned with the child's broader social development (Stevenson and Nerison-Low, 2002). This social system makes education as the first, peers as the second, and family as the third. According to the way the advertisement portrays this young man's story, it seems the sequence shows the importance in the levels of the social community. The advertising shows that school may be considered as the first important social challenge while the family is placed in the third position. It does depend, though, on how people see the hierarchy in their society and culture, as the nearest relationship or the function of it. The family is the first agent of socialization, but the development of adolescent age makes the function and effectiveness of the family as a social space shifted by school and peers (Boundless, 2014). Families, peers, and schools are the primary areas for young people to construct their realities. In here, the advertising sort is based on social function.

The forth-social obstacle that the young western man passed was an office/company job. After passing through the periods of their lives, the job or working place becomes the next symbol of 
one's future. It is like a connotative meaning of a life's journey that is increasingly advancing.

In Chinese advertising, the first challenge that he faced and passed was his family. In Confucian teachings, it is considered that "family" is the prototype of all social organizations. Confucianism is like social cement that fixes family members in the network of their appropriate hierarchical relationships (Waley, 2012) and then is transferred to social organizations.

The second obstacle the young Chinese man faced was his job/career. Social hierarchy in the office is also the same with the family. In China, occupation proves someone's success results. The topic on occupation and salary is part of the common things to be asked in that culture. In Chinese advertising, the school and peers societies were not shown. If compared with the global advertising, it seems the school and peer cultures are not very important for the Chinese. Schooling is important for Chinese, but making friends after class and a part-time job are not really common or encouraged in China. Academic results are considered very important for Chinese students and their family. They spend much time in self-studying after class in empty classrooms or a library; not like Western students who emphasize on social relations. The Chinese student considers exam scores as the most important rather than socializing with their peers in order to get the recognition and approval from their family and elders.

The connotation level in this specific global advertisement shows the family importance is based on social functions, but school is more important because of the need in spending more time socializing and networking in school. School, peers, family and office are grouped according to their function as a social circle. In the Chinese ad, a family is important based on the relationship. The family and vocation grouped by the relationship of father and child, boss and worker. Confucius also defined human relationships as "Ruler-subject, father-son, husband-wife, big brother-younger brother, and friend-friend" (Waley, 2012). Although both ads show family and career, it is in a different perspective depending on which commercial one watches. Western classify on the basis of rule-based category membership, whereas East Asians classify objects and events on the basis of relationships and family resemblance (Chiu, 1972; Norenzayan et al., 2002; Nisbett and Masuda, 2003). The pictures the in connotation level show the social system in the west. Schools have an important role in shaping an individual and the Confucius system also places the family as the first in all things. 
Serat Rupa Journal of Design, May 2017, Vol.1, No.3: 475-495

Elizabeth Susanti Gunawan, Semiotic Analysis of adapted Advertising Communication

Between China and Western Pepsi"Rising" Global Advertising

\section{Father or Mother}

In the young Western man's house, there was a father, mother, and sister. In denotation level, the ad shows the father that plays the role to persuade the young man. The father can then be considered to be the head of the family that rules and guides the family and also a friendly relations with children. As a low power distance country, the relationship between parents and children are equal (Hofstede, 2011). In the Chinese advertisement, within the young man's house, there was only a father and mother; there was no sister or brother. China instituted a one-child policy (dushengzinü zhengce) (1979-2015) which, in a sense, has been represented by displaying the young man as an only child. It is not common to see a Chinese family with some children. In the Chinese Pepsi commercial, the mother plays the role to persuade the young man while the father sits and 'glares' at the young man. A Chinese proverb says "strict father, kind mother" (yanfucimu) was a stereotype of Chinese mothers and fathers in playing very different roles in educating children. The fathers' principal duties were to provide economic support, moral instruction, and a suitable inheritance for their sons while the mothers developed very intense, emotional relationships with their children that were not seen between fathers and children (Wolf, 1970). Fathers' roles are as a disciplinarian who should "not encourage or tolerate emotional indulgence" and the mothers' roles are to provide a "secure and loving environment within the home" (Jankowiak, 1992:347). In the Chinese announcement, the father's role was replaced with the mother to persuade the young man, but the young man does not appear to be disobedient to his mother. If the father was talking to him in the advertising the young man would be considered to be disobedient because of the hierarchy of the relationship between a father and the children in China as a high power distance country. In China, a mother focuses on harmonious relationships within the family and seems to have a softer relation than a stricter one like with the father. The global and the Chinese advertisement do not only show a different role of a father or mother in persuading the young man in the denotation level, but also contain a deep social value of the Western and Eastern power distance relationship.

\section{Climbing Top to The Mound}

In the denotation level, these scenes show the use of a shorter time for global advertisement than for Chinese advertisement. In global advertisement, it shows a scene about the young man reaching towards the top of the mound, which was within 3.5 seconds of the full 58 seconds 
video. The Chinese ad took 4.5 seconds from the 29 seconds allotment for the young man to reach the top. A longer time scene makes it look like the result of reaching the top is considered more important within the Chinese commercial. The emphasis in the ad from China is the result of being successful and prospering. In connotation level, China as collectivism is concerned with the result that he can show to the public; and the result of doing activities is more important.

The Chinese infomercial added a speaker at the summit of the mound which, in the global advertisement there was no speaker on the mound. The commercial for China not only shows the process of reaching the top as the denotative meaning, but the in connotation level they want to emphasize the result of hard and challenging work. At the top, there is a speaker as the ultimate goal. In the denotation level, a speaker is an essential piece of equipment to be prepared for concert events, or various other uses. In the connotation level, it does not only emphasize the symbol to hold a big concert but also to strengthen the further goal of success in social recognition.

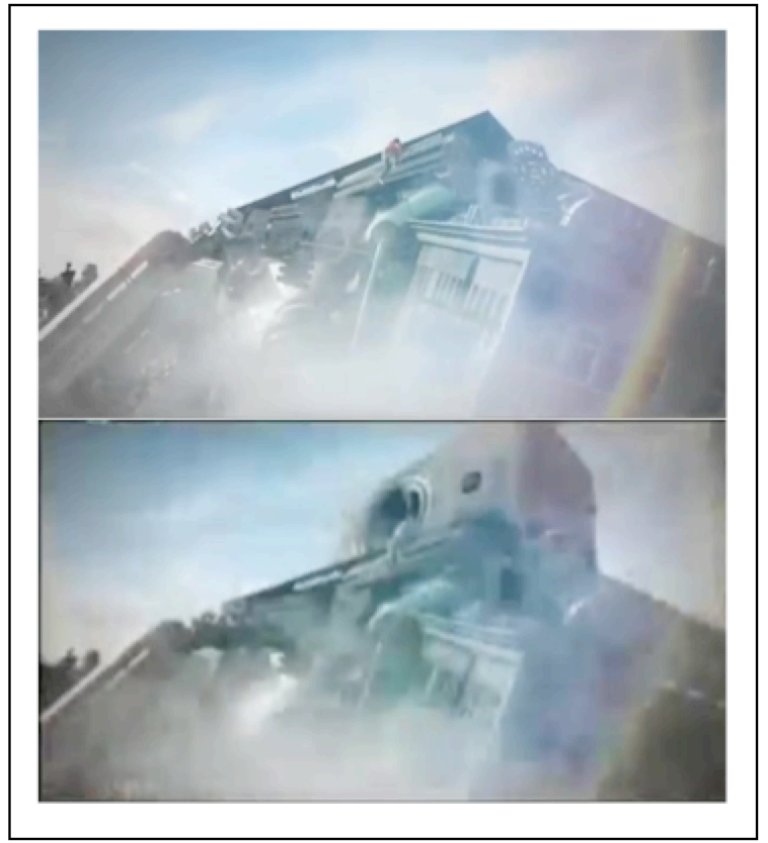

Figure 5. American advertising and Chinese advertising: without or with speaker on the top (Source: https://www.youtube.com/watch?v=OCmd5bUu_U0; https://www.youtube.com/watch?v=_oqn0KH3YJM)

In denotation level, the Pepsi global commercial displays the young man climbing up to the top with a smiling face, and he climbed to the top of the mound by himself. It shows that he's happy and proud of achieving this goal independently. In the connotation level, it shows how the individualistic culture of people trying to individually reach their goal. On the side of the 
Chinese ad, when the young man almost reaches the top, he looks up to observe the top and from the top, there is Asia's Pepsi ambassador Cai Yilin who reaches out to lend a helping hand and invite him up. The Chinese advertisement has Cai Yilin appear not only as a symbol of helping others but also signifies the ultimate 'dream' for many young people due to her hard work in the music industry, being possible to be successful like her as a big star which is supposedly what the young man sought as his goal. In the connotation level, the role of Cai Yilin at the end of the story was not to just represent that one can become as popular as her, but also to weaken the individualistic impression. Success is not only on the scale of self-effort but is also about the support of others. In a collective culture, where belongingness and respect are key social hierarchy values, a celebrity that is widely recognized and represents the shared values of society may be considered more credible and influential to bring credibility and product support for their symbolic transfer.

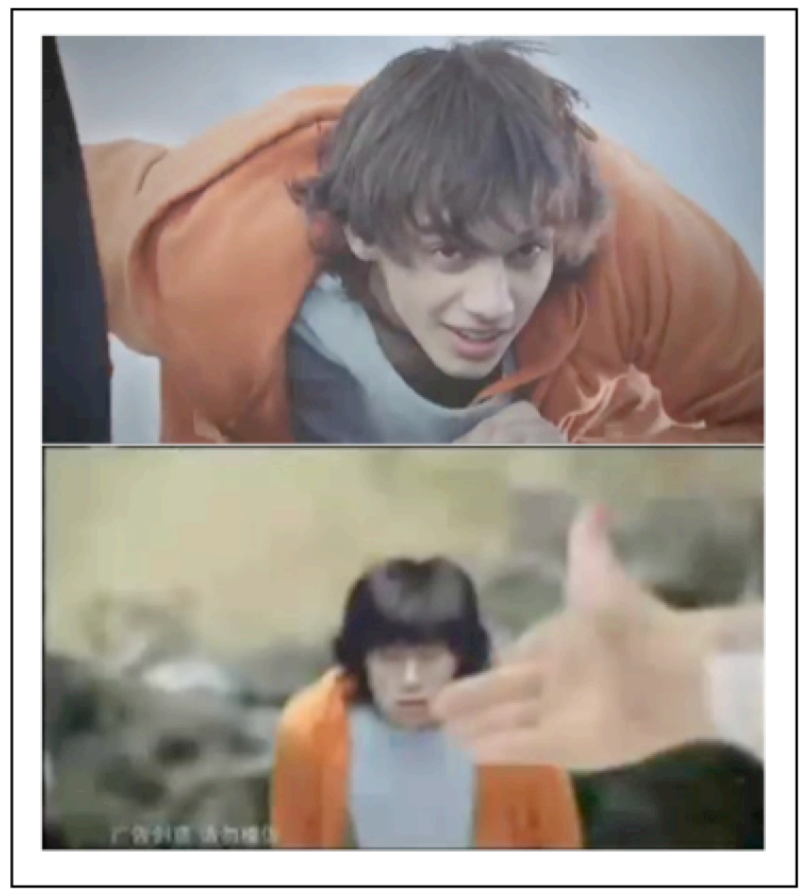

Figure 6. American advertising and Chinese advertising: without or with woman (Source: https://www.youtube.com/watch?v=OCmd5bUu_U0; https://www.youtube.com/watch?v=_oqn0KH3YJM)

In the denotation level of the global infomercial, it shows when the young man arrived at the top; within there was a white guitar in front of him. He reaches for the guitar and starts to sing on stage, without any visible attributes of Pepsi whatsoever. However, within the Chinese commercial, when the young man arrives at the top, there is a guitar with red white and blue colors like Pepsi's logo colors; and there is also a very big Pepsi logo on the stage floor. When 
the scene shows him on stage, the background behind the stage was an image of a bottle of Pepsi. The young man's guitar and one other player's guitar also in red, white and blue color like Pepsi's colors. Displaying corporate identity logos are more often seen in Asian advertisings than in Western (Souiden et al., 2006).

In the connotation level, this global advertisement communicates the story about a successful young man on the stage after he climbed through all the difficulties while the Chinese ad clearly wants to show the correlation between Pepsi products and the successful story of a young man who consumed Pepsi before climbing a large mound of difficulties. Ji, Guo, Zhang, and Messervey (2009) suggest that the Chinese may view the past as a background for the present, leading to more proximal perception as compared to Western.

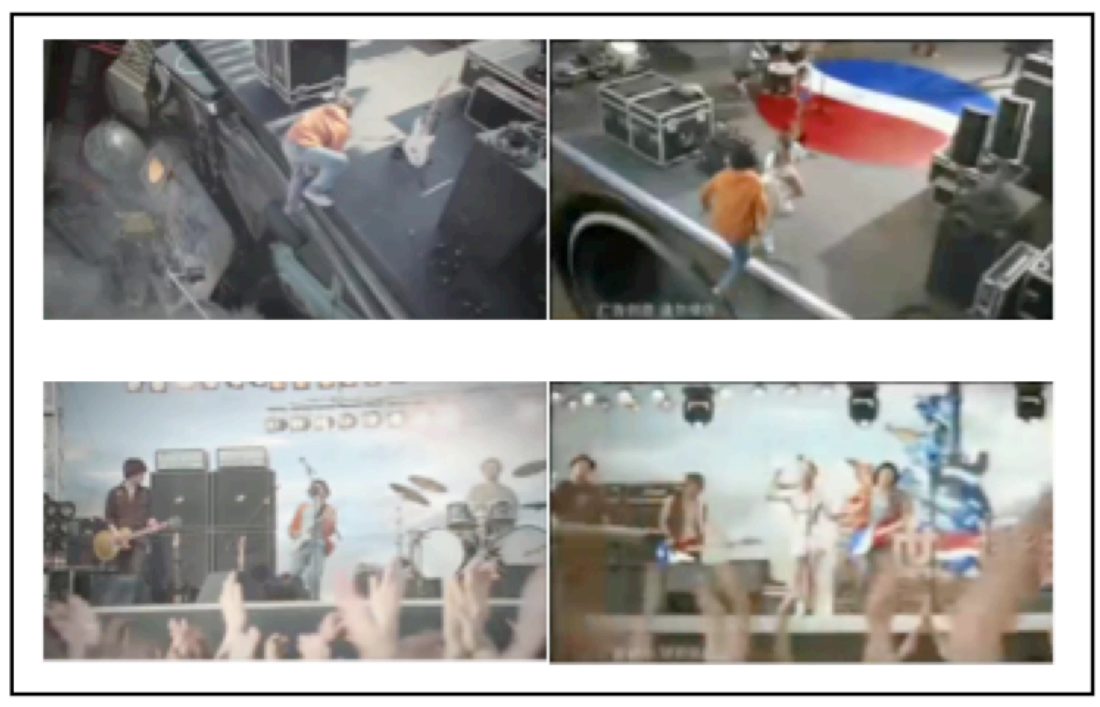

Figure 7. American advertising and Chinese advertising: without or with Pepsi attribute (Source: https://www.youtube.com/watch?v=OCmd5bUu_U0; https://www.youtube.com/watch?v=_oqn0KH3YJM)

\section{Shouting on Stage}

The denotation level in the global ad shows the young man looks up, with his chin slightly upward, but the eyes look down. With the head lifted high and the chin jutting forward could possibly signal superiority, fearlessness, arrogance, power and aggression (Pease and Pease, 2008:233). In the denotation level, the young man looked confident and proud of the achievement that he, himself, has done. The young man shouted with a very deep feeling of getting into his own world. The existence of audiences was as a form of affirmation that he was great; he was the one who holds the superior role among many people. In the connotation level, it shows self-achievement as a self-success because of his independent thinking and actions. 
Western believes in the power of self-determination, individualism, and parents encouraging their children to discover themselves freely and joyfully (Doctoroff, 2012). In the denotation level, the young man in the Chinese commercial has his head straight and eyes looking forward. The man seemed to blend with the audience when he was shouting; there seems to be the success of himself by the assistance and support of the audience. In the connotation level, it can be observed that personal success is the result of others assistance and it was also shared with the others.

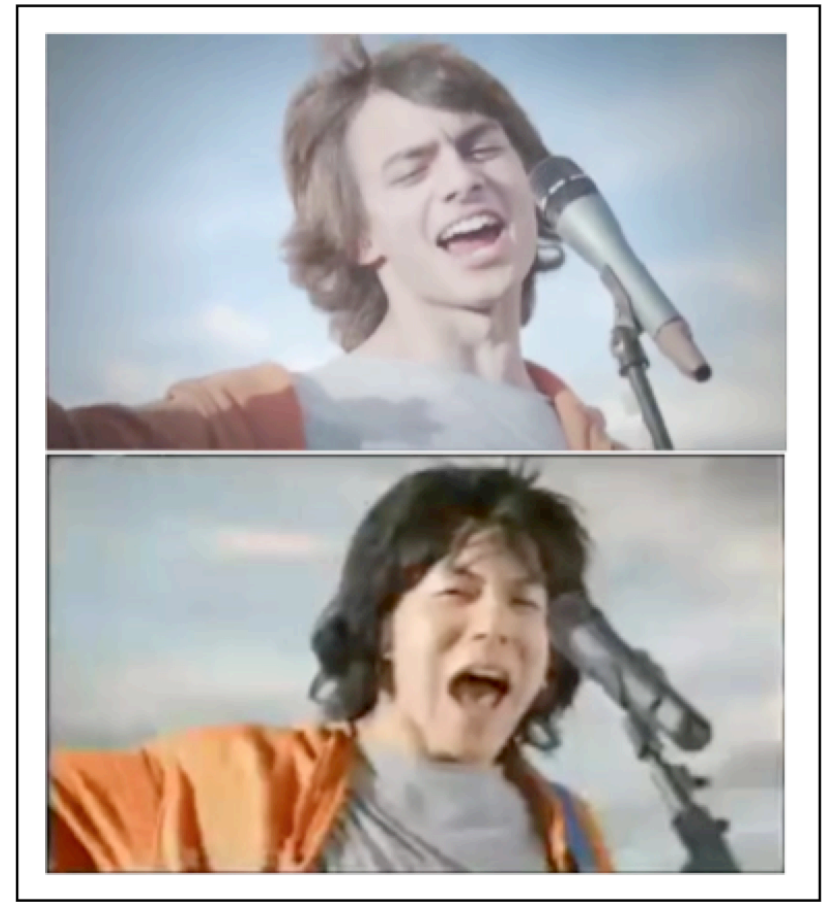

Figure 8. American advertising and Chinese advertising: young man shouting gesture (Source: https://www.youtube.com/watch?v=OCmd5bUu_U0; https://www.youtube.com/watch?v=_oqn0KH3YJM)

\section{Campaign Slogan}

In the denotation level of the video from global advertising, it shows the campaign slogan "I can". 'Can' is to be able to do, make, or accomplish; to have knowledge or skill ("Can", 2015). The world behind "I can" must be an activity (verb). "I can" has a meaning that "I am able to do, I have the ability'. The sentence emphasizes the idea about an activity that one is able to do as an individual. They exist as an individual, and being individualistic can make anything possible. The young man was very confident with himself and there was no need for recognition from others, and he to present a Western style tends to be much more individualistic. An individualistic society is characterized by the citizen who seeks to promote their own interests (Moorman and 
Blakely, 1995). In the connotation level of the global commercial, the advertising made Pepsi as a symbol of an individual success brand. On the other hand, the denotation of Chinese advertisement shows the campaign slogan as "Baishi wochuang ". The addition of the "Pepsi" word behind the Pepsi logo looks like a double, but for Chinese advertising, the emphasized is that this is a Pepsi product advertising promotion. China, as a country, uses the logogram letters to read the letters like viewing images. The role of a logo becomes ineffective because it does not stand out among the Chinese logogram like the picture. "Baishi wochuang" in English means "Pepsi I create". Create is to make or produce (something); to cause (something new) to exist; to produce (something new, such as a work of art) by using your talents and imagination ("Create", 2015). The word behind "I create" must be a material in nature (object). "I create" means to make something to prove oneself and to get approval from others. "I create" is not about one person, but about belonging to make material and sharing with each other with a social community. One can succeed and exist because of the recognition from other people about what was made/ created. In the connotation level, "Pepsi I create" means with Pepsi they can make something so the others can enjoy it together. A collectivistic society such as China is characterized by citizens who seek to support the goals of the group and protect group welfare (Moorman and Blakely, 1995). In Chinese advertising, the particular advertisement made Pepsi contain a connotative meaning as a togetherness consumer product.

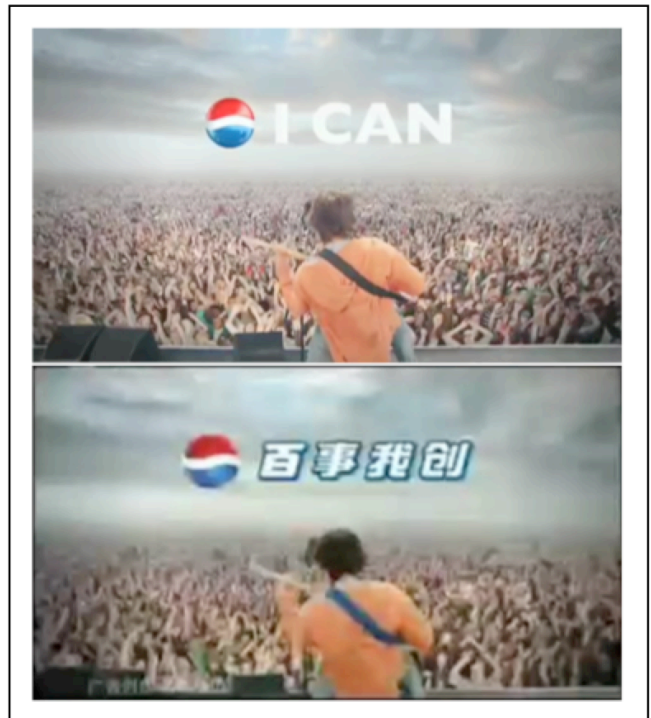

Figure 9. American advertising and Chinese advertising: "I can" or "Pepsi I create" (Source: https://www.youtube.com/watch?v=OCmd5bUu_U0; https://www.youtube.com/watch?v=_oqn0KH3YJM) 
Serat Rupa Journal of Design, May 2017, Vol.1, No.3: 475-495

Elizabeth Susanti Gunawan, Semiotic Analysis of adapted Advertising Communication

Between China and Western Pepsi"Rising" Global Advertising

\section{Ideology: Individualism vs. Collectivism}

These two similar advertisements show a similar denotative sign, but a totally different connotative meaning. In the connotation level it clearly shows how culture works in pictures, which is represented in the denotation level. In the ideology level, it shows how ideology plays an important role in organizing stories, and adding or changing elements to show different ideologies. The advertisements show the Western culture with its individualistic ideology and the Chinese culture with its collective ideology. Many people in Western countries are individualism, which decision-making and actions are made individually. In global advertising, many people are discouraging the young man's dream, but as people are equal, it is not rude to keep climbing to reach his dream and enjoy the success alone. In Chinese advertisement when the young man did not listen to his parents or boss it seemed very individualistic, but there were still some aspects that made the advertisement not too individualistic. The Chinese young generation is living in the Chinese cultural context but also have an almost constant contact with Western culture, they may have been influenced by the ideas, values, conventions, and behaviors of Western culture and exhibit the new cultural features. However, their individualistic tendencies are in terms of freedom rather than individualism (Moore, 2005). The Chinese culture of regimented social structures is still very strong for China's individuals to be totally Western.

Chinese young people are not a carbon copy of Western styles, although they reflect Western kinds of modernity and individualism. The young man in the Chinese ad seems very individualistic, he was looking for his own way to get the goal, but his cultural value still appeared in how the other helped him to reach his goal, and how he shared his success. From the outside view, Chinese youth seemed to follow the progress of globalization by accepting the Western culture, but actually, they still respect the existing social structure. The individual of new generation young people in the global ad was adapted from a focus on 'me' as the only man who can reach the top, became 'we' were together to reach our successful. 
Serat Rupa Journal of Design, May 2017, Vol.1, No.3: 475-495

Elizabeth Susanti Gunawan, Semiotic Analysis of adapted Advertising Communication

Between China and Western Pepsi"Rising" Global Advertising

\section{CONCLUSION}

Pepsi advertisement for global and for China have highly similar pictures but offer a different brand positioning. The global-localized process of a brand is not a purely translational construct, but has a deliberate transformational design to change the cultural value of the message. Chinese advertising seems to copy the global advertising in the whole with changing the actor(s). The localized advertisement through the adaptation of the complete story, the duration of time for each activity, the gestures, the tools, the social societies, parents-child relation, the background and the campaign contain not only a denotative meaning, but also a connotative meaning that communicates different values, which position the brand in an entirely different value system. Semiotic analysis helps interpret the meaning of every transformational element in an advertisement. Through the semiotic analysis of the global advertising and the Chinese advertising, we identify some connotations, such as low context culture/ high context cultures, mono-chronic culture/ poly-chronic cultures, process orientations/ result orientations, taking risks/ seeking knowledge, social societies/ Confucius influences, equal power distance/ hierarchical power distance, and individual cultures/ collective cultures. All these differences present Pepsi in a different value of brand positions. Global Pepsi positions the brand with the Western individualistic value, daring to take risks, making it ok to ignore the social society to be yourself, enjoying the result (Pepsi) alone. On the other hand, China Pepsi positions the brand with mixed individual-collective culture, which means they know what they want, but they do not totally ignore the society and share the result (Pepsi) together.

A Pepsi advertisement that presents the Western culture will not be accepted if they do not present any localized ideologies. To be accepted in China or any specific country with unique cultural features, the advertisement has to notice every little aspect that can present a connotative and ideological meaning of it. Standardized advertising can be made with a very similar execution but with small changes in the elements that content a different connotation meaning, which can alter the ideology of the message within. Some other countries, especially India, have a different cultural value from the one of the western culture, but Pepsi uses the same ad for India market. It shows that there are other aspects considered when they decided that different culture still can use the same ad. For the Chinese market, they decided to remake the ad with a highly similar picture but with ideology adapted. 
This article only focused on the adapted Chinese Pepsi advertisement. A further research can be conducted to more specifically analyze why they chose such picture in creating the ad for the western market. This analysis can still be opened to various alternative interpretations and not be restrictive in the concluding meaning, based on the cultural background of each interpreter. This study enables the opening of another conclusion.

\section{REFERENCES}

Barcus, F. E., and Wolkin, R. (1977). Children's Television: An Analysis of Programming and Advertising. New York: Praeger Publishers

Barker, C. (2000). Cultural studies: Theory and practice. London: Sage.

Barthes, R. (1967), Elements of Semiology. New York: Hill and Wang. . (1972). Mythologies. New York: Macmillan.

Berger, A. A. (1991). Media analysis techniques. USA: Sage Publications.

Doctoroff, T. (2012). What Chinese want: culture, communism, and the modern Chinese consumer. UK: Macmillan.

Gunawan, E. S., \& van den Hoven, P. (2017). Global Brand Identity as a Network of Localized Meanings. International Journal of Marketing Studies, 9(2), 56.

Hall, E. T. (1976). Beyond culture. New York: Anchor Press.

Jankowiak, W. (1992). Father-child relations in urban China. In B. S. Hewlett (Ed.), Father-child relations: Cultural and biosocial contexts. New York: De Gruyter.

Pease, B., and Peace, A. (2008). The definitive book of body language. USA: Bantam.

Robertson, R. (1992). Globalization: Social theory and global culture (Vol. 16). UK: Sage.

Waley, A. (2012). The Analects of Confucius. New York: Routledge.

Wolf, M. (1970). Child training and the Chinese family. In M. Freedman (Ed.), Family and kinship in Chinese societies. Palo Alto, CA: Stanford University Press.

\section{Journal \& Online Reference}

Boundless. "Family, Peers, Church, and School." Boundless Political Science. Boundless, 03 Jul. 2014. Retrieved 08 May. 2015 from https://www.boundless.com/politicalscience/textbooks/301/public-opinion-6/forming-public-opinion-45/family-peers-churchand-school-260-5674/ 
Can. (2015). In Merriam-Webster. Retrieved from http://www.merriam-webster.com

/dictionary/can

Chiu, L. H. (1972). A cross-cultural comparison of cognitive styles in Chinese and American children. International Journal of Psychology, 7(4), 235-242.

Cho, B., Kwon, U., Gentry, J. W., Jun, S., and Kropp, F. (1999). Cultural values reflected in theme and execution: A comparative study of US and Korean television commercials. Journal of Advertising, 28(4), 59-73.

Create. (2015). In Merriam-Webster. Retrieved from http://www.merriam-webster.com

/dictionary/create

Demaine, E. D., Demaine, M. L., Eisenstat, S., Lubiw, A., and Winslow, A. (2011). Algorithms for solving Rubik's cubes. In Algorithms-ESA 2011 (pp. 689-700). Springer Berlin Heidelberg.

Hofstede, G. (2011). Dimensionalizing cultures: The Hofstede model in context. Online readings in psychology and culture, 2(1), 9.

Ji, L. J., Guo, T., Zhang, Z., and Messervey, D. (2009). Looking into the past: Cultural differences in perception and representation of past information. Journal of Personality and Social Psychology, 96(4), 761-769.

Kaufman, C. F., Lane, P. M., and Lindquist, J. D. (1991). Exploring more than 24 hours a day: A preliminary investigation of polychronic time use. Journal of Consumer Research, 18(3), 392-401.

Moore, R. L. (2005). Generation Ku: Individualism and China's millennial youth. Ethnology, 357376.

Moorman, R. H., and Blakely, G. L. (1995). Individualism-collectivism as an individual difference predictor of organizational citizenship behavior. Journal of organizational behavior, 16(2), 127-142.

Nisbett, R. E., and Masuda, T. (2003). Culture and point of view. Proceedings of the National Academy of Sciences, 100(19), 11163-11170.

Norenzayan, A., Smith, E. E., Kim, B. J., and Nisbett, R. E. (2002). Cultural preferences for formal versus intuitive reasoning. Cognitive Science, 26(5), 653-684.

Samiee, S., Jeong, I., Pae, J. H., and Tai, S. (2003). Advertising standardization in multinational corporations: The subsidiary perspective. Journal of Business Research, 56(8), 613-626.

Souiden, N., Kassim, N. M., and Hong, H. J. (2006). The effect of corporate branding dimensions on consumers' product evaluation: A cross-cultural analysis. European Journal of 
Serat Rupa Journal of Design, May 2017, Vol.1, No.3: 475-495

Elizabeth Susanti Gunawan, Semiotic Analysis of adapted Advertising Communication

Between China and Western Pepsi"Rising" Global Advertising

Marketing, 40(7/8), 825-845.

Stevenson, H. W., and Nerison-Low, R. (2002). To Sum It Up: Case Studies of Education in Germany, Japan, and the United States.

Tai, S. H. (1997). Advertising in Asia: localize or regionalize?. International Journal of Advertising, $16(1), 48-61$.

\section{Video Reference}

YouTube. 2009. Chinese Pepsi advertisement

YouTube. 2009. Pepsi Global advertisement 